\title{
A High Performance Thin Layer Chromatographic Method Using a Design of Experiment Approach for Estimation of Phytochemicals in Extracts of Moringa Oleifera Leaves
}

\author{
Yüksek Performanslı İnce Tabaka Kromatografi Yöntemi ile Moringa Oleifera \\ Yaprak Ekstrelerindeki Fitokimyasalların Deney Tasarımı Yaklaşımı ile Tayini
}

\author{
(D) Asha THOMAS ${ }^{1 *}$, (D) Abhilash KANAKDHAR , (D) Adinath SHIRSAT2, (D) Sanjeevani DESHKAR ${ }^{3}$, (D) Lata KOTHAPALLI \\ 1Dr. D.Y. Patil Institute of Pharmaceutical Sciences and Research, Clinic of Pharmaceutical Chemistry, Maharashtra, India \\ 2Peptide-Formulation Development (NDDS), Sun Pharmaceutical Industries Ltd, Vadodara, India \\ ${ }^{3}$ Dr. D.Y. Patil Institute of Pharmaceutical Sciences and Research, Clinic of Pharmaceutics, Maharashtra, India
}

\begin{abstract}
Objectives: A systematic design of experiment (DoE) based sensitive, robust high performance thin layer chromatographic (HPTLC) method was established for simultaneous estimation of gallic acid (GA), quercetin (QT), and rutin (RT) from ethanolic and aqueous leaf extracts of Moringa oleifera.

Materials and Methods: The chromatographic separation was carried on Merck TLC aluminum sheets of silica gel 60 F254 (10×10 cm) with mobile phase of toluene: ethyl acetate: methanol: formic acid (4.9:4.1:2:0.5, v/v/v/v) with densitometric scanning at $300 \mathrm{~nm}$. The critical method parameters were initially identified by regular two level factorial design and further systematically optimized using a central composite design, evaluating the effect on selected critical analytical attributes, retention factor (RF), and peak area.

Results: The Pareto charts, 3D response surface plots, and polynomial equations for the generated models suggested significant influence of the selected factors on responses of QT, GA, and RT. The desirability and overlay plots employed provided appropriate solutions that were experimentally validated. Under the optimized conditions, the biomarkers were suitably resolved with RF values of $0.64 \pm 0.02,0.80 \pm 0.03$, and $0.22 \pm 0.02$ for $\mathrm{GA}$, QT, and RT, respectively, with wide linear dynamic range (200-1200 ng/band each), high accuracy (98.1-99.4\%), and intra- and interday precision (\%RSD <2\%). When employed for quantification of these biomarkers in Moringa oleifera extracts, the ethanolic and aqueous extracts exhibited higher content of QT $(993.5 \mu \mathrm{g} / \mathrm{g}$ and $832 \mu \mathrm{g} / \mathrm{g}$, respectively). The ethanolic extract showed a larger amount of RT (701 $\mu \mathrm{g} / \mathrm{g})$. In contrast, aqueous extract exhibited a higher proportion of GA $(591.1 \mu \mathrm{g} / \mathrm{g})$ compared to ethanolic extract $(150 \mu \mathrm{g} / \mathrm{g})$.

Conclusion: This validated HPTLC method developed through a DoE approach was successfully employed for quantification of GA, QT, and RT from Moringa oleifera extracts and may also be extended for their simultaneous estimation in other herbal extracts, thereby reducing time, and may serve as a cost effective tool for analysis.
\end{abstract}

Key words: DoE, gallic acid, HPTLC, Moringa oleifera, quercetin, rutin

Öz

Amaç: Moringa oleifera yapraklarının etanol ve su ile hazırlanan ekstrelerinde gallik asit (GA), kersetin (QT) ve rutin (RT) miktarlarının eşzamanlı olarak tayin edilebilmesi amacıyla sistematik deney tasarımına (DoE) dayalı hassas ve güçlü yüksek performanslı ince tabaka kromatografisi (HPTLC) yöntemi geliştirilmiştir.

Gereç ve Yöntemler: Kromatografik ayırım Merck TLC Silika Jel Plakada 60 F254 (10×10 cm) hareketli faz olarak tolüen: etil asetat: metanol: formik asit $(4,9: 4,1: 2: 0,5 ; \mathrm{h} / \mathrm{h} / \mathrm{h} / \mathrm{h})$ kullanılarak ve $300 \mathrm{~nm}$ 'de yoğunluk taraması yapılarak gerçekleştirilmiştir. Kritik yöntem parametreleri ilk olarak iki faktöryelli deney tasarımı ile belirlenmiş daha sonra bu parametreler seçilen kritik analitik özellikler, alıkonma faktörü ve pik alanı üzerindeki etkileri değerlendirilerek merkez kompozit tasarım kullanılarak sistematik olarak optimize edilmiştir.

*Correspondence: E-mail: asha.thomas@dypvp.edu.in, Phone: +09881236220 ORCID-ID: orcid.org/0000-0003-1058-8779

Received: 09.07.2018, Accepted: 06.12.2018

๑Turk J Pharm Sci, Published by Galenos Publishing House. 
Bulgular: Üretilen modeller için oluşturulan Pareto çizelgeleri, 3B yanıt yüzey grafikleri ve polinom denklemleri, seçilen faktörlerin QT, GA ve RT yanıtları üzerine anlamlı etkileri olduğunu göstermiștir. Uygulanan istenebilirlik ve bindirme grafikleri ile deneysel olarak doğrulanmış uygun

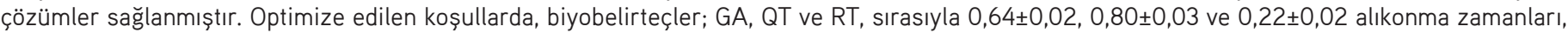
geniş doğrusal dinamik aralık (herbiri 200-1200 ng/bant), yüksek doğruluk (\%98,1-99, 4) ve gün içi ve günler arası kesinlik (\%RSD <\%2) ile uygun șekilde ayrılmıştır. Bu biyobelirteçlerin Moringa oleifera ekstrelerindeki miktar tayininde etanol ve su ile hazırlanan ekstrelerde daha yüksek QT içeriği saptanmıștır (sırasıyla 993,5 $\mu \mathrm{g} / \mathrm{g}$ ve $832 \mu \mathrm{g} / \mathrm{g}$ ). Etanol ile hazırlanan ekstrede daha fazla RT (701 $\mu \mathrm{g} / \mathrm{g}$ ) olduğu görülmüștür. Bunun tersine, su ile hazırlanan ekstrede gözlenen GA $(591,1 \mu \mathrm{g} / \mathrm{g})$ oranının, etanol ile hazırlanan ekstreye $(150 \mu \mathrm{g} / \mathrm{g})$ göre daha yüksek olduğu tespit edilmiştir.

Sonuç: DoE yaklaşımı ile geliştirilen bu geçerli HPTLC yöntemi, Moringa oleifera ekstrelerinden GA, QT ve RT miktar tayinleri için başarıyla kullanılmıştır ve bu yaklaşımın diğer bitkisel ekstrelerde de bu biyobelirteçlerin miktarlarının eşzamanlı olarak tayin edilebilmesini sağlayarak analiz süresini kısaltacağı ve maliyet tasarrufu sağlayacağı düșünülmüștür.

Anahtar kelimeler: DoE, gallik asit, HPTLC, Moringa oleifera, kersetin, rutin

\section{INTRODUCTION}

In recent years people have been consuming large quantities of herbal medicines for various therapeutic and prophylactic purposes due to their implied safety, efficacy, cultural acceptability, and lesser side effects. Herbs are a rich source of various phytoconstituents, among which phenolic acids and flavonoids are present in major proportions. Around 300 flavonoids have been isolated and their pharmacological activities have been extensively studied to date. Most of them are reported to be less toxic to humans and therefore are widely used in herbal medicine.

Flavonoids like quercetin (QT), rutin (RT), and phenolics like gallic acid (GA) are present in a large number of herbs and herbal preparations. QT is a natural polyphenolic present in vegetables, fruits, and juices and has been extensively studied for numerous biological activities. Chemically, QT is an aglycone of RT and other glycosides and is a powerful antioxidant and free radical scavenger. RT is used in the treatment and prevention of small varicose veins. This substance is also used in mesotherapy or intradermotherapy to stimulate circulation in treatment against cellulite. It has been used for preparing patients with jaundice for surgery. GA is a polyphenolic compound with antioxidant properties and is used to treat the common cold and fever and as a diuretic, laxative, liver tonic, restorative, antipyretic, and anti-inflammatory agent. ${ }^{2}$ Figure 1 represents the chemical structures of these biomarkers.

Currently, the literature indicates that there are very few methods reported for the quantitative estimation of these biomarkers present in herbs/herbal preparations. Recently, Amir et al. ${ }^{3}$ reported an high performance thin layer chromatographic (HPTLC) method for the simultaneous estimation of QT and RT in herbs. Hussain et al. ${ }^{4}$ reported an HPTLC method employing

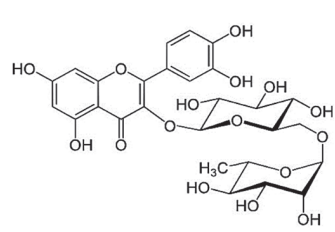

(a)

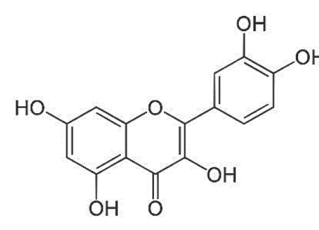

b)<smiles>O=C(O)c1cc(O)c(O)c(O)c1</smiles>

(c)
Figure 1.Chemical structure of RT (a), QT (b) and GA (c)

QT: Quercetin, RT: Rutin, GA: Gallic acid toluene: ethyl acetate: formic acid (5:4:1) as the mobile phase for determination of QT and GA in Abutilon indicum. Alam et al. ${ }^{5}$ also reported normal phase-HPTLC for estimation of RT, GA, QT, and naringenin in extracts of Guiera senegalensis. However, individual mobile phases consisting of acetonitrile: water (4:6) were employed for estimation of RT and QT, while a mixture of toluene: ethyl acetate and formic acid (6:4:8) was used for determination of GA and naringenin.

Seal reported a reversed phase-High performance liquid chromatography (HPLC) method employing acetonitrile and $1 \%$ aqueous acetic acid solution as mobile phase in gradient mode with photodiode array detection at 272, 280, and 310 $\mathrm{nm}$ for simultaneous quantitation of flavonoids (catechin, RT, QT, myricetin, apigenin, and kaempferol) in wild edible leaves of Sonchus arvensis and Oenanthe linearis. ${ }^{6}$ A sensitive ultra performance liquid chromatography-ESI-MS/MS method employing protein precipitation is reported for estimation of phytoconstituents in Polygonum capitatum extract in rat plasma, namely phenolic acids and flavonoids like GA, quercitrin, and QT. ${ }^{7}$ Alam et al. ${ }^{8}$ also reported a HPLC method for the estimation of RT, QT, and GA in Moringa oleifera plants native to Saudi Arabia. A preliminary thin layer chromatography study using $0.2 \%$ 2.2-diphenyl-1-picrylhydrazyl as the spraying reagent and HPLC on a $\mathrm{C} 18$ reverse-phase column was employed for quantitation of GA and RT in extracts of $C$. alata and Andrographis paniculata. ${ }^{9}$ Sajeeth et al. ${ }^{10}$ reported a HPTLC method on precoated HPTLC silica gel 60 F254 plates employing toluene: ethyl acetate: formic acid (7:5:1 v/v/v/v/v) as mobile phase for quantitative estimation of GA, RT, and QT from Eruca sativa extract. Another HPTLC method on precoated silica gel GF 254 plates using toluene: acetone: glacial acetic acid (3:1:2 v/v/v/v/v) as mobile phase with ultraviolet (UV) detection at $254 \mathrm{~nm}$ for GA [retention factor (RF) 0.30] and a mixture of ethyl acetate: dichloromethane: formic acid: glacial acetic acid: water (10:2.5:1:1: 0.1, v/v/v/v/v) at $366 \mathrm{~nm}$ for RT and QT at an RF value of 0.13 and 0.93 , respectively, is reported." While the literature reports suggest that there are few HPTLC methods for estimation of QT, RT, and GA, these methods have employed different mobile phase compositions/different wavelengths of detection for estimation of these biomarkers. To date, there is no reported HPTLC method employing a design of experiments (DoE) approach for the simultaneous estimation of these three biomarkers in combination. 
Moringa oleifera, native to India or Sub-Himalayan areas and widely spread throughout the tropical and subtropical areas, is a miracle tree and an unbelievable source of all nutrients, with various pharmacological effects in several disease conditions for its antibacterial, antidiabetic, and cardiovascular effects, and also for the treatments of stomach aches, sprains, and fever. Moringa oleifera contains GA, QT, and RT in considerable proportions and its anti-atherosclerotic, antioxidative, and antidiabetic activities have been reported. ${ }^{12}$

Recently HPTLC has been introduced in the USP as an official tool for analysis, mainly for the quantitative and qualitative analysis of herbal extracts. HPTLC, because of its highly sensitive detection ability and other advantages like low operating cost, high sample throughput, and minimum sample clean-up requirement, is now adopted for analysis as an alternative to HPLC.

DoE as per (ICH) Q2 (R1), Q8 (R2), and Q9 guidelines is a systematic approach for analytical method development and validation. Various designs can be adopted for screening and optimization of method variables that can influence the method responses. Regular two-level factorial screening is an excellent design for initial screening of variables that can affect the responses. Furthermore, for optimization of analytical method parameters, central composite design (CCD) is one of the most widely used designs, allowing better understanding of not only the main effect (effect of each individual variable selected through screening design) but also their interaction effects. A DoE approach helps to reduce the number of experiments to be performed, thereby proving to be a simple, economic, less time consuming, and robust strategy for method development. ${ }^{13}$

The present study reports for the first time the quantitative estimation of GA, QT, and RT by HPTLC method developed through a DoE approach and its application for estimation of these bioactive agents in Moringa oleifera leaf extracts.

\section{MATERIALS AND METHODS}

\section{Plant collection and identification}

Fresh leaves of Moringa oleifera were collected from the area around Pune. The collected parts of Moringa oleifera were authenticated at the Botanical Survey of India, Pune.

\section{Chemicals and reagents}

GA (99\%), RT (98\%), and QT (99\%) were purchased from $\mathrm{Hi}$ Media Laboratories, Mumbai, India. All chemicals and reagents were of AR grade and aluminum-backed TLC plates precoated with a $0.2 \mathrm{~mm}$ layer of silica gel $60 \mathrm{~F} 254(10 \times 10 \mathrm{~cm})$ were purchased from E. Merck (Germany).

\section{Standard preparation}

A suitable quantity ( $5 \mathrm{mg}$ ) each of GA, QT, and RT was weighed accurately and transferred to separate $10 \mathrm{~mL}$ volumetric flasks, $5 \mathrm{~mL}$ of methanol was added followed by sonication for $10 \mathrm{~min}$, and the volume was made up to $10 \mathrm{~mL}$ with methanol. The resulting solutions were filtered through Whatman filter paper and suitable volumes were applied to TLC plates for further analysis.

\section{Sample preparation}

Preparation of ethanolic and aqueous extracts of Moringa oleifera

Fresh leaves of Moringa oleifera were ground into small pieces. For the preparation of ethanolic extract, the powdered plant material was macerated with $70 \%$ ethanol $(1: 40 \mathrm{w} / \mathrm{v})$ for 72 hour at room temperature $\left(28 \pm 2{ }^{\circ} \mathrm{C}\right)$ with occasional shaking.

Aqueous extract was prepared by maceration of powdered plant leaves with distilled water for 24 hour at room temperature $\left(28 \pm 2^{\circ} \mathrm{C}\right)$ with occasional shaking.$^{14}$

The extracts were filtered through Whatman filter paper and the resulting marcs were re-macerated with the same solvent until complete extraction. The residual solvents were removed using rotary evaporation and then dried using a vacuum oven (Labline) under pressure at $40^{\circ} \mathrm{C}$ to obtain dry extracts.

\section{HPTLC instrumentation and chromatographic conditions}

A Camag HPTLC system equipped with a TLC scanner 3 and win CATS 1.2.2 software (Camag, Muttens, Switzerland), a UV chamber (Camag, Muttens, Switzerland), a twin trough chamber $(10 \times 20 \mathrm{~cm}$ or $20 \times 20 \mathrm{~cm}$; Camag, Muttens, Switzerland), and a saturation pad (Camag, Muttens, Switzerland) was used. The standards and samples were spotted in the form of bands of width $6 \mathrm{~mm}$ with a Camag microliter syringe on aluminum plates precoated with silica gel 60 F254 $(10 \times 10 \mathrm{~cm}$ with 0.2 $\mathrm{mm}$ thickness, E. Merck, Germany) using a Camag Linomat V (Hamilton, Broadus, Switzerland) sample applicator. The slit dimension was kept constant at $5 \mathrm{~mm} \times 0.45 \mathrm{~mm}$ and the scanning speed was maintained at $20 \mathrm{~mm} / \mathrm{s}$. Linear ascending development was carried out in the twin trough glass chamber and the chromatograms were developed up to a length of 80 $\mathrm{mm}$. The developed TLC plates were dried with the help of an air dryer.

\section{Preliminary HPTLC analysis}

Initial HPTLC trials were carried out employing solvents like toluene, isopropanol, n-butanol, methanol, ethyl acetate, formic acid, dioxane, and acetic acid in varying proportions as mobile phase. However, problems like low RF values for RT (<0.05), overlapping of the peaks of QT and GA, and large RF values for QT (>0.90) were observed. The addition of methanol resulted in improvement in the RF values of RT and QT. However, change in the proportion of methanol ( $>3$ and $\langle 2$ ) resulted in a considerable effect on the RF value of QT and RT. Taking this into consideration and after several permutations and combinations, a mixture of toluene, ethyl acetate, methanol, and formic acid (4:3:2:0.5 v/v/v/v) was selected as the mobile phase as it gave relatively fair separation of GA, QT, and RT. The trials suggested that there was a major influence of chromatographic method conditions on the RF value and peak area of the three biomarkers.

\section{Method development and optimization using DoE}

Further to the initial trails, a DoE approach was employed in the present study to identify and understand the influence of the method conditions on the analytical output through a thorough 
understanding of the process. The predetermined objective of the present study was to identify the best/optimum conditions for effective separation of the selected biomarkers and study the influence of the method parameters on the identified critical analytical attributes (CAAs) (RF value and peak area).

\section{Factor screening studies}

Initially, based on the literature data, experimental trial results, and elaborate analysis using Ishikawa fishbone diagrams, six factors, i.e. method parameters (mobile phase ratio, time from spotting to chromatography, time from chromatography to scanning, wavelength, activation time, and saturation time) were selected for the study. The regular two-level factorial screening design using Design Expert software version 11 (Stat-Ease, Minneapolis, MN, USA) was initially employed for selection of critical method parameters (CMPs) that will influence the (CAAs). A design matrix comprising 8 experimental runs was suggested, considering two levels (low and high) for each selected method parameter. The levels selected were mobile phase ratio (4:5); saturation time (10 min: $20 \mathrm{~min}$ ); time from spotting to chromatography (10 $\mathrm{min}: 30 \mathrm{~min})$; time from chromatography to scanning (10 min: $30 \mathrm{~min}$ ); wavelength (254 $\mathrm{nm}$ : $300 \mathrm{~nm}$ ); activation time (5 min: $15 \mathrm{~min}$ ). The Pareto charts were employed to evaluate the influence of each factor (CMPs) on selected CAAs. The polynomial equations were generated for each model as given below:

$Y=\beta_{0}+\beta_{1} X_{1}+\beta_{2} X_{2}+\beta_{12} X_{1} X_{2}+\beta_{11} X^{2}+\beta_{22} X^{2}{ }_{2}+\varepsilon$,

where $Y$ is the measured CAA associated with each factor level combination; mobile phase composition (toluene content) $\left(X_{1}\right)$ and time from spotting to chromatography $\left(X_{2}\right)$. The composition of the mobile phase refers to the volume of toluene with respect to the total volume of the mobile phase. The low, medium (nominal value), and high levels of dependent and independent variables were selected based on the results from preliminary experimentation. The nominal value for two factors, toluene content $\left(X_{1}\right)$ and time from spotting to chromatography $\left(X_{2}\right)$, were $4 \mathrm{~mL}$ and $10 \mathrm{~min}$, respectively. Accordingly, the toluene content $\left(X_{1}\right)$ was maintained between $4 \mathrm{~mL}$ and $5 \mathrm{~mL}$. Similarly, the low and high values of the time from spotting to chromatography $\left(X_{2}\right)$ were fixed at $15 \mathrm{~min}$ and $25 \mathrm{~min}$, respectively.

Optimization of HPTLC method parameters using a central composite design

Central composite response surface design was employed to optimize the CMPs as selected through their initial screening design. The screening design was used to optimize the compositional parameters and to evaluate interaction effects and quadratic effects of the selected method parameters, i.e. the mobile phase ratio and time from spotting to chromatography. The design was specifically selected since it requires fewer runs than a Box-Behnken design in the case of two variables. A design matrix comprising 14 experimental runs was constructed (Table 1).

\section{Validation of the proposed HPTLC method}

The proposed HPTLC method for simultaneous estimation of QT, RT, and GA was validated as per ICH guidelines.

\section{Linearity (calibration curve)}

Standard solutions of GA, QT, and RT were prepared in methanol to obtain a concentration of $0.5 \mathrm{mg} / \mathrm{mL}$. Different volumes of standard solutions were spotted on the TLC plates in triplicate using a Camag Linomat $\mathrm{V}$ sample applicator to obtain bands in the concentration range of $200-1200 \mathrm{ng} /$ band for GA, QT, and RT. The plates were then developed and the data of peak areas versus drug concentrations were treated by linear least squares regression analysis to obtain the regression equations.

\section{Accuracy (recovery \%)}

The accuracy of the method was determined by calculating recoveries of GA, QT, and RT by the standard addition method. Known amounts of standard solutions of GA, QT, and RT were added at $80 \%, 100 \%$, and $120 \%$ level to prequantified sample solution (extracts). The amounts of GA, QT, and RT were estimated by applying obtained values to the respective regression line equations.

\section{Precision}

The precision of the system was determined by measuring repeatability of sample application and measurement of peak areas for three replicates at each concentration level. To evaluate intraday precision, three mixed standards were prepared. Suitable volumes $(0.4 \mu \mathrm{L}, 1.2 \mu \mathrm{L}, 2 \mu \mathrm{L})$ were applied to HPTLC plates to obtain standard bands corresponding to three concentrations $(200,600$, and $1000 \mathrm{ng}$ ) in triplicate on the same day. For the intraday precision (intermediate precision), the assays was performed on three consecutive days and the peak areas were recorded. The precision of the system and method was expressed as relative standard deviation (RSD) \% of peak area.

\section{Statistical analysis}

All the data analysis was carried out in replicates and standard deviation and RSD values were computed.

The present study does not require ethics committee approval or patient informed consent.

\section{RESULTS AND DISCUSSION}

\section{Factor screening studies}

The analysis of data obtained using the regular two-level factorial design for screening of CMPs suggested that the

Table 1. Optimization trials of central composite design (where $X_{1}$ toluene content, $X_{2}$ time from spotting to chromatography)

\begin{tabular}{lllllllllllllll} 
Run & 1 & 2 & 3 & 4 & 5 & 6 & 7 & 8 & 9 & 10 & 11 & 12 & 13 & 14 \\
\hline$X_{1}$ & 4.5 & 4.5 & 4.5 & 6 & 6 & 3 & 3 & 4.5 & 4.5 & 2.78 & 6.62 & 4.5 & 4.5 & 4.5 \\
\hline$X_{2}$ & 20 & 20 & 20 & 10 & 30 & 10 & 30 & 20 & 34.14 & 20 & 20 & 5.85 & 20 & 20 \\
\hline
\end{tabular}


composition of the mobile phase ratio had a significant negative impact on the retention factor of QT (-83.70\%) and GA (-89.51\%). In the case of RT, the method parameter of time from spotting to chromatography had a major effect on the RF value (-38.82\%). For the CAA of peak area, the wavelength of detection and time from chromatography to scanning contributed significantly in the case of QT, RT, and GA. However, mobile phase ratio and time from chromatography to spotting were critical for RT (Figure 2).

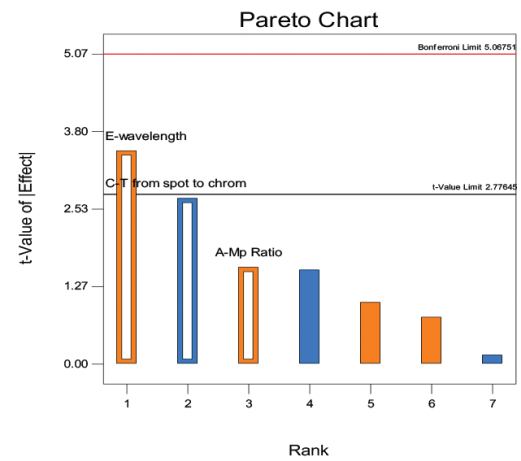

(a)

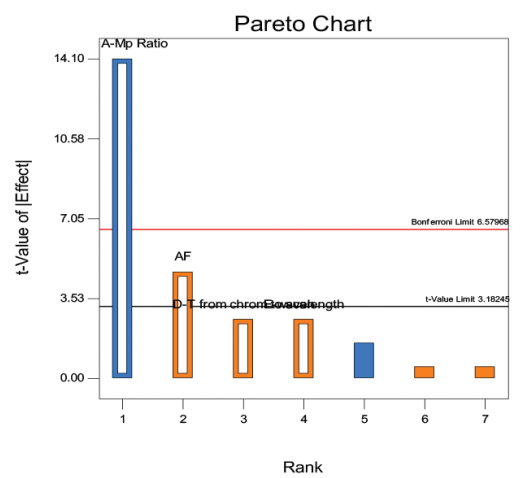

(c)

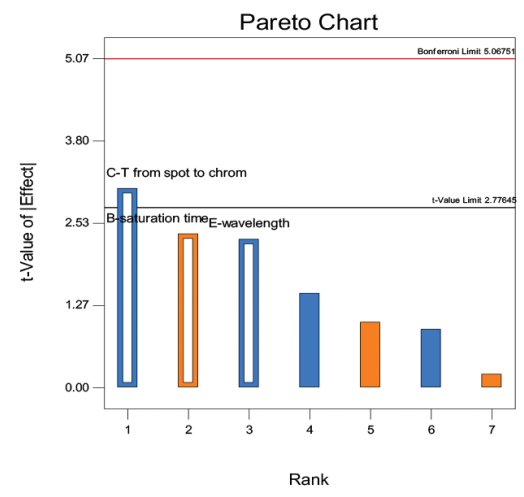

(e)

\section{Optimization of CMPs using a central composite design}

Based on the results of the preliminary screening design, it was thought appropriate to further optimize the effect of the identified CMPs (mobile phase ratio and time from spotting to chromatography) on selected analytical attributes (RF and peak area) using a CCD.

The selected CMPs, namely mobile phase ratio and time from spotting to chromatography, were studied at five levels $(-\alpha,-1$, $0,1,+\alpha)$. The design matrix comprised a total of 14 experimental

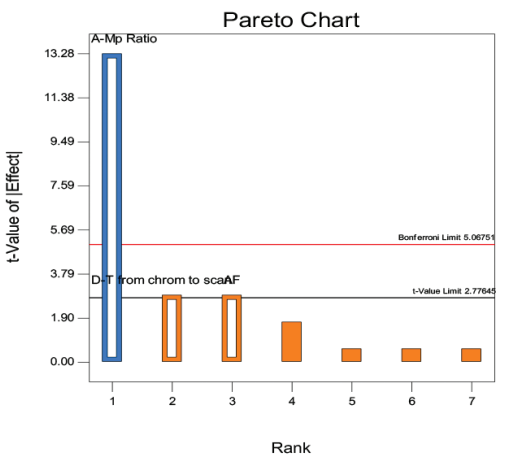

(b)

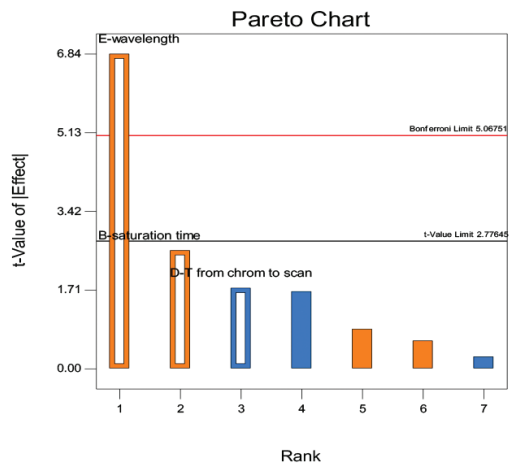

(d)

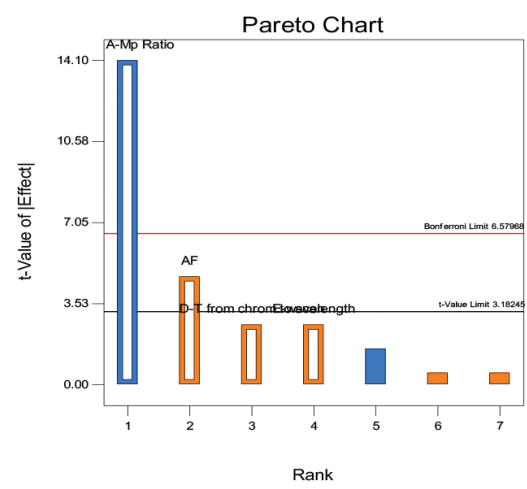

(f)

Figure 2. Pareto charts depicting the influence of CMP's on method CAA, (a) Effect on area of QT, (b) Effect on Rf of QT, (c) Effect on area of GA, (d) Effect on Rf of GA, (e) Effect on area of RT, (f) Effect on Rf of RT

CMP's: Critical method parameters, CAA: Critical analytical attributes, QT: Quercetin, GA: Gallic acid, Rf: Retardation factor, RT: Rutin 
runs with 6 runs at the center point $(0,0)$. Standard RT, GA, and QT were prepared at the concentration of $400 \mathrm{ng} / \mathrm{band}$ and used for all experimental runs. Design Expert 10 software was employed for the data analysis.

Data validation was performed by one way analysis of variance (ANOVA) combined with the $F$ test. Coefficients that were found to be significant $(p<0.05$ ) were considered in framing the polynomial equations. Lack of fit and correlation coefficients $\left(r^{2}\right)$ were employed further to evaluate the appropriateness of model fitting (Tables 2 and 3). 2D contour plots and 3D response surface plots (Figure 3) were employed for response surface analysis. The entire model's diagnostic plots like the normal plot of probability, run plot, residual plots, and histogram plots were also employed to evaluate the degree of fitness of the data

\section{Table 2. Summary of statistical ANOVA for response ( $Y_{1}$ retardation factor)}

\begin{tabular}{|c|c|c|c|c|c|c|c|c|c|c|c|c|c|c|c|}
\hline \multirow{2}{*}{ Source } & \multicolumn{3}{|c|}{ Sum of squares } & \multicolumn{3}{|c|}{ Degree of freedom } & \multicolumn{3}{|c|}{ Mean square } & \multicolumn{3}{|c|}{$F$ value } & \multicolumn{3}{|l|}{$\mathrm{p}$ value } \\
\hline & QT & RT & GA & QT & RT & GA & QT & RT & GA & QT & RT & GA & QT & RT & GA \\
\hline Model & 0.044 & 0.000 & 0.06 & 2 & 0 & 2 & 0.022 & - & 0.03 & 8.97 & - & 4.97 & 0.006 & - & 0.032 \\
\hline$X_{1}$ & 0.043 & - & 0.06 & 1 & - & 1 & 0.043 & - & 0.06 & 17.39 & - & 9.06 & 0.002 & - & 0.013 \\
\hline$x_{2}$ & $\begin{array}{l}1.337 \\
\text { E-003 }\end{array}$ & - & $\begin{array}{l}5.386 \\
E-003\end{array}$ & 1 & - & 1 & $\begin{array}{l}1.337 \\
\text { E-003 }\end{array}$ & - & $\begin{array}{l}5.386 \\
E-003\end{array}$ & 0.54 & - & 0.88 & 0.4793 & - & 0.3706 \\
\hline Residual & 0.025 & 0.037 & 0.061 & 10 & 12 & 10 & $\begin{array}{l}2.476 \\
E-003\end{array}$ & $\begin{array}{l}3.069 \\
\text { E-003 }\end{array}$ & $\begin{array}{l}6.128 \\
\text { E-003 }\end{array}$ & - & - & - & - & - & - \\
\hline Lack of fit & 0.018 & 0.011 & 0.041 & 6 & 8 & 6 & $\begin{array}{l}3.083 \\
E-003\end{array}$ & $\begin{array}{l}1.320 \\
E-003\end{array}$ & $\begin{array}{l}6.869 \\
E-003\end{array}$ & 1.97 & 0.20 & 1.37 & 0.2669 & 0.97 & 0.3969 \\
\hline
\end{tabular}

ANOVA: One way analysis of variance, QT: Quercetin, RT: Rutin, GA: Gallic acid

Table 3. Summary of statistical ANOVA for response $\left(Y_{2}\right.$ area)

\begin{tabular}{|c|c|c|c|c|c|c|c|c|c|c|c|c|c|c|c|}
\hline Source & \multicolumn{3}{|c|}{$\begin{array}{l}\text { Sum of } \\
\text { squares }\end{array}$} & \multicolumn{3}{|c|}{$\begin{array}{l}\text { Degree of } \\
\text { freedom }\end{array}$} & \multicolumn{3}{|l|}{$\begin{array}{l}\text { Mean } \\
\text { square }\end{array}$} & \multicolumn{3}{|c|}{$F$ value } & \multicolumn{3}{|c|}{$p$ value } \\
\hline Model & 98.9 & 185.3 & 937.6 & 3 & 3 & 5 & 32.95 & 61.76 & 187.5 & 1.00 & 5.82 & 5.72 & 0.435 & 0.017 & 0.020 \\
\hline$X_{1}$ & 11.6 & 122.3 & 252.8 & 1 & 1 & 1 & 11.64 & 122.2 & 252.8 & 0.35 & 11.5 & 7.71 & 0.566 & 0.008 & 0.027 \\
\hline$X_{2}$ & 51.2 & 14.01 & 394.6 & 1 & 1 & 1 & 51.22 & 14.01 & 394.6 & 1.56 & 1.32 & 12.0 & 0.243 & 0.280 & 0.010 \\
\hline
\end{tabular}

\begin{tabular}{lllllllllllllllll}
\hline Residual & 295.7 & 95.58 & 229.3 & 9 & 9 & 7 & 32.9 & 10.62 & 32.76 & - & - & - & - \\
\hline Lack of fit & 258.4 & 52.91 & 202.5 & 5 & 5 & 3 & 51.7 & 10.58 & 67.51 & 5.54 & 0.99 & 10.0 & 0.061 & 0.5175 & 0.025 \\
\hline
\end{tabular}

ANOVA: One way analysis of variance, QT: Quercetin, RT: Rutin, GA: Gallic acid

\section{Table 4. Predicted/observed results of solutions suggested by Design Expert software}

\begin{tabular}{|c|c|c|c|c|c|c|c|c|}
\hline Solution results & $\begin{array}{l}\text { Mob. phase } \\
\text { (T:EA:M:FA) }\end{array}$ & $\begin{array}{l}\text { Time from spotting to } \\
\text { chromatography (min) }\end{array}$ & RF & & & $\%$ Cont & & \\
\hline Predicted results & & & GA & QT & RT & GA & QT & RT \\
\hline Solution 1 & 4.9:4.1:2:0.5 & 26.2 & 0.63 & 0.77 & 0.23 & 98 & 103 & 102 \\
\hline Solution 2 & 4.8: 4.2:2:0.5 & 21.6 & 0.63 & 0.75 & 0.23 & 97 & 102 & 102 \\
\hline Solution 3 & 5.2: 3.8:2: 0.5 & 26.1 & 0.62 & 0.75 & 0.23 & 97 & 102 & 101 \\
\hline Solution 4 & 5.3: 3.7:2:0.5 & 26.1 & 0.62 & 0.75 & 0.23 & 96.8 & 102 & 101 \\
\hline Observed results & & & GA & QT & RT & GA & QT & RT \\
\hline Solution 1 & 4.9: 4.1:2:0.5 & 26.2 & 0.64 & 0.77 & 0.23 & 99.56 & 100.1 & 101.8 \\
\hline Solution 2 & 4.8: 4.2:2:0.5 & 21.6 & 0.65 & 0.78 & 0.24 & 99.5 & 995 & 102 \\
\hline Solution 3 & 5.2: 3.8:2:0.5 & 26.1 & 0.57 & 0.73 & 0.19 & 97 & 99.4 & 98.4 \\
\hline Solution 4 & 5.3: 3.7:2:0.5 & 26.1 & 0.65 & 0.78 & 0.24 & 98 & 99 & 98.11 \\
\hline
\end{tabular}

RF: Retention factor, QT: Quercetin, RT: Rutin, GA: Gallic acid, T: Toluene, EA: Ethyl acetate, M: Methanol FA: Formic acid 


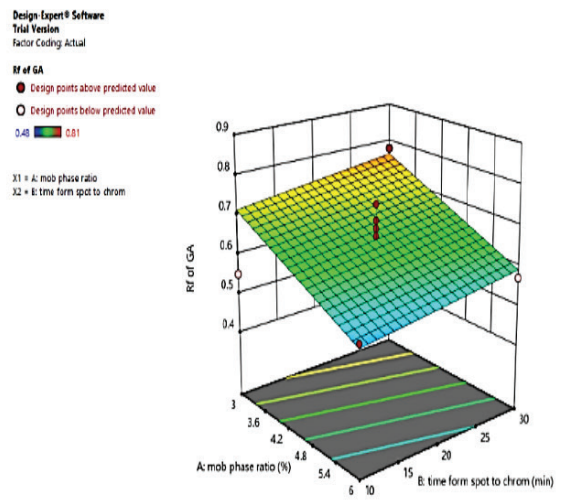

(a)

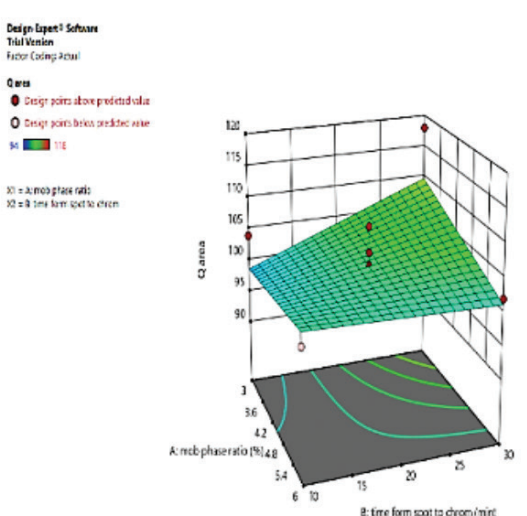

(d)
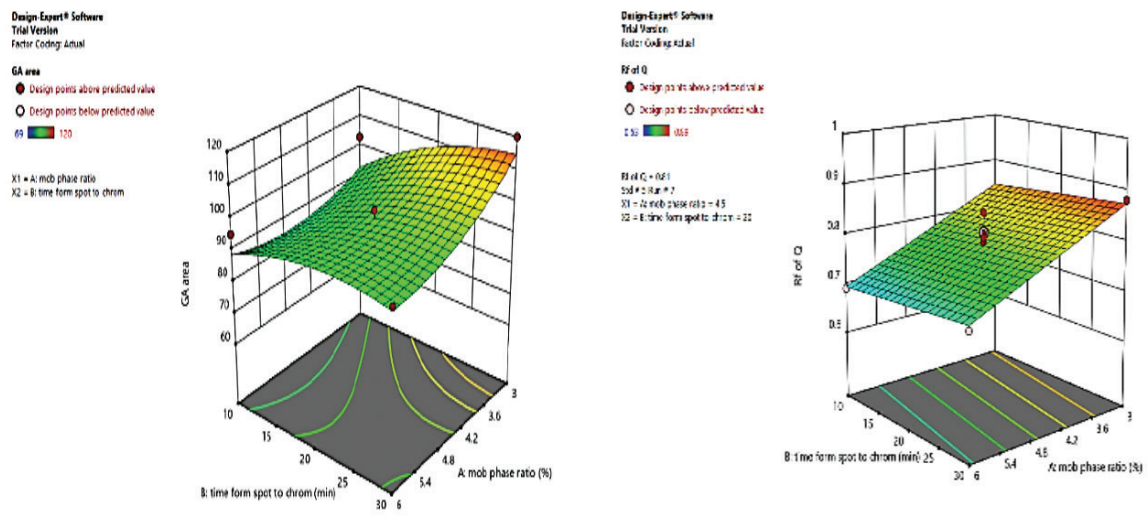

(b)

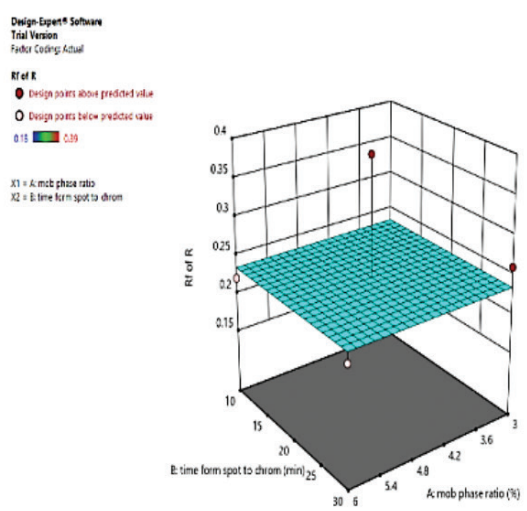

(e)

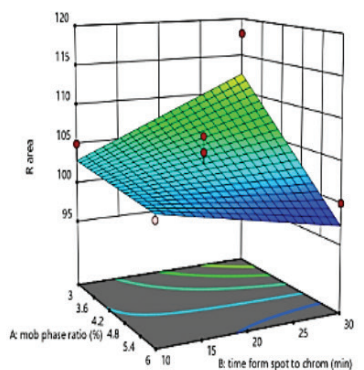

(f)

Figure 3. 3D Response surface plots showing the effect of mobile phase composition and time from spotting to chromatography on RF and area of biomarkers (a) Effect on the area of QT, (b) effect on RF of QT, (c) effect on the area of GA, (d) effect on RF of GA, (e) effect on the area of RT (f) effect on RF of RT

QT: Quercetin, RF: Retention factor, GA: Gallic acid, RT: Rutin

obtained. All the experimental runs were carried out in random order to avoid any bias in measurement.

\section{Effect on retention factor and peak area of gallic acid}

The results of the ANOVA of the model to represent the effect of selected CMPs ( $X_{1}$ mobile phase ratio and $X_{2}$ time from spotting to chromatography) on responses (selected CAAs) $Y_{1}(R F)$ and $Y_{2}$ (area) are summarized in Tables 2 and 3, respectively. The $3 \mathrm{D}$ response surface plots were also analyzed.

For GA, the polynomial equation model generated suggested that factors $X_{1}$ and $X_{2}$ were statistically significant $(p<0.05)$. It was observed that as the mobile phase ratio varied (amount of toluene increased), it had a small negative impact on the RF value as indicated by a negative coefficient $(-0.058)$. For the response $Y_{2}$ (peak area), the factor $X_{1}$ (mobile phase ratio) had a significant negative influence (-17.80). However, as the time from spotting to chromatography increased, the area under the curve of GA increased up to a certain point, above which it further decreased. An interaction effect of selected factors was also observed.

\section{Effect on retention factor and peak area of quercetin}

In the second model generated for the influence of factors $X_{1}$ and $X_{2}$ on responses $Y_{1}$ and $Y_{2}$ of $Q T$, the polynomial equation and model developed were also statistically significant ( $p<0.05$ ). Here the factor $X_{1}$ (mobile phase ratio) had a negative impact on the $R F$ value $\left(Y_{1}\right)$ as demonstrated through the response surface plot. However, the effect of $X_{2}$ on response $Y_{2}$ (peak area) was nonsignificant ( $p>0.05$ ), indicating that the selected method parameters were robust and did not have any significant impact on the area of QT.

\section{Effect on retention factor and peak area of rutin}

For RT, the generated model was nonsignificant $(p>0.05)$ for $X_{1}$ and $X_{2}$ on selected response $Y_{1}(R F)$ of $R T$, indicating that there was no significant difference in the RF value of RT under the selected method conditions. However, it was observed that the polynomial equation for factor $X_{1}$ and $X_{2}$ had a significant positive impact $(p<0.05)$ on the peak area of RT as indicated by the positive coefficient $(+1.93$ and +1.18 , respectively). An interaction effect of $X_{1}$ and $X_{2}$ was also observed. 
In order to obtain the best chromatographic performance, the multicriteria methodology was employed by means of Derringer's desirability function. Individual desirability functions ranging from 0 (undesired response) to 1 (fully desired response) were selected. A value of $D$ close to 1 indicates that combination of different criteria is globally optimal. The red area in the desirability plot indicates that the prediction at all
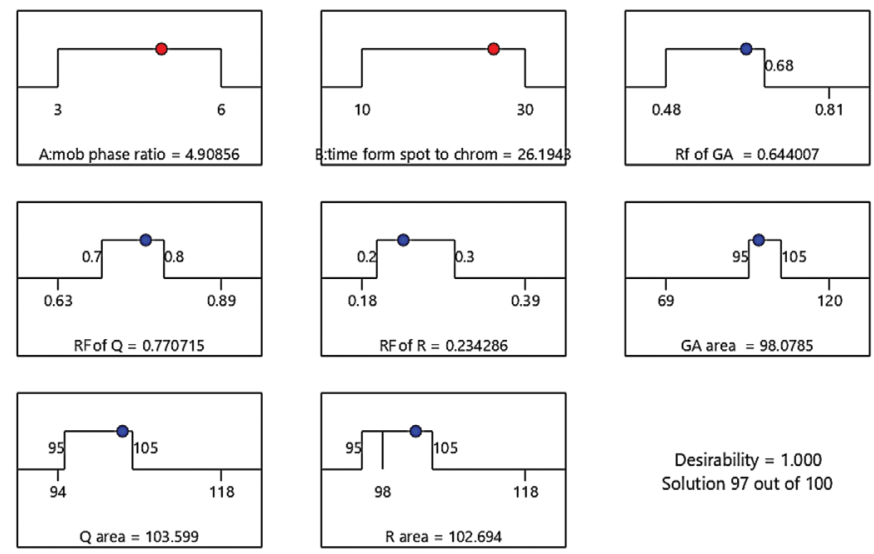

Desirability $=1.000$ Solution 97 out of 100

Figure 4. Optimized conditions on response basis: Desirability=1 RF: Retention factor, GA: Gallic acid

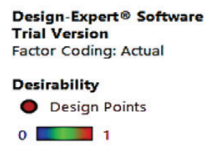

$\mathrm{X} 1=\mathrm{A}:$ mob phase ratio $\times 2=$ in time form spot to chrom

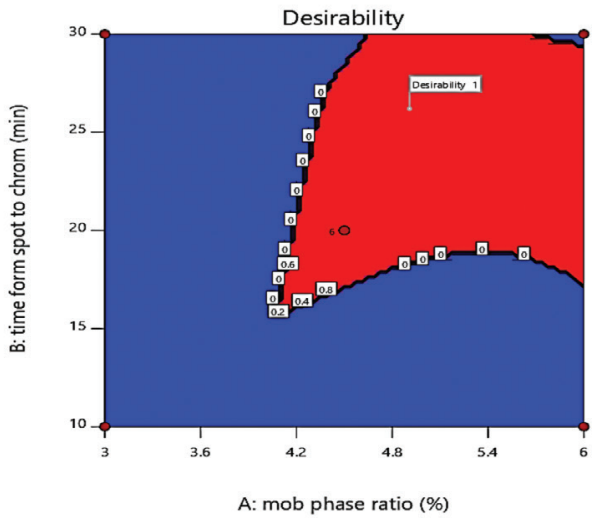

Figure 5. Desirability showing the effect of mobile phase composition and time from spotting to chromatography on Rf and area of GA, QT and RT

QT: Quercetin, RF: Retention factor, GA: Gallic acid, RT: Rutin
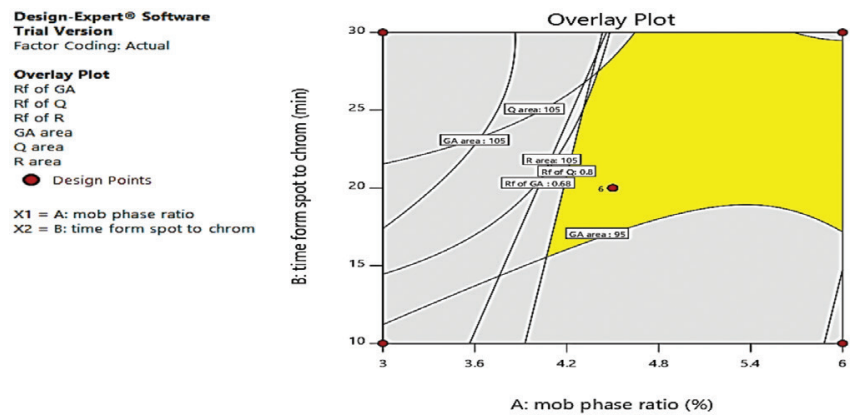

Figure 6. Overlay plot showing the effect of mobile phase composition and time from spotting to chromatography on retardation factor and peak area on GA, QT and RT

QT: Quercetin, GA: Gallic acid, RT: Rutin, RF: Retention factor points in this region is one. The yellow area in the overlay plot indicates that all the constraints are satisfied in this region. Desirability (Figures 4 and 5) and overlay plots (Figure 6) were obtained from the models for the selected responses. The desirability and overlay plots gave the design space within which variations in CPPs did not affect the CAAs selected. However, four solutions as suggested by the software were selected such that they satisfied the desirability function of 1 and were also observed in the yellow zone in the overlay plot.

The four proposed solutions were experimentally run under the stated conditions and the resulting densitograms were evaluated to observe any deviations in RF and peak areas from the predicted values (Figure 7). The agreement between the experimental and predicted responses was assessed by calculating the percentage of prediction error using the following formula: Predicted error=Experimental responsePredicted response/predicted responsex100.

The results of the same are summarized in Table 4. From the data generated and prediction error calculations, it was observed that the \% prediction error calculated for RF and \% content of the three biomarkers were minimal in the case of solution 1. The \% error for RF and \% content of GA were 1.58 and 1.59, respectively, where the amount of toluene in the mobile phase was high $\left(X_{1}=4.9 \mathrm{~mL}\right)$ and time from spotting to chromatography was also large $\left(X_{2}=26.2 \mathrm{~min}\right)$. However, the RF values of QT and RT were found to exactly match the predicted values, while $\%$ error for \% content was significantly low (-2.81\% for QT and $-0.19 \%$ for RT). The desirability study indicated that solution 1 gave more accurate results and therefore these optimized conditions [mobile phase composition: toluene: ethyl acetate: menthol: formic acid solution (4.9:4.1:2:0.5 v/v/v/v) and time from spotting to chromatography: $26 \mathrm{~min}$ ] were selected for further validation studies.

\section{Validation of the proposed HPTLC method \\ Linearity (calibration curve)}

The linear regression data obtained for the calibration curves $(n=6)$ showed an excellent linear relationship over a wide concentration range of 200-1200 ng/band for GA, QT, and RT (Table 5).

\section{Precision}

The measurement of peak area in the interday and intraday precision studies showed low \% RSD ( $<2 \%)$, which suggested precision of the method (Table 5).

\section{Recovery}

The accuracy of the proposed HPTLC method demonstrated through recovery studies performed by spiking sample with pure drugs at $80 \%, 100 \%$, and $120 \%$ indicated good recovery of the three biomarkers with \% recovery in the range of $98.1-99.4 \%$ (Table 5).

\section{Determination of GA, QT, and RT in leaf extracts of Moringa} oleifera

The densitograms obtained on analysis of the ethanolic and aqueous extracts of Moringa oleifera showed three well 

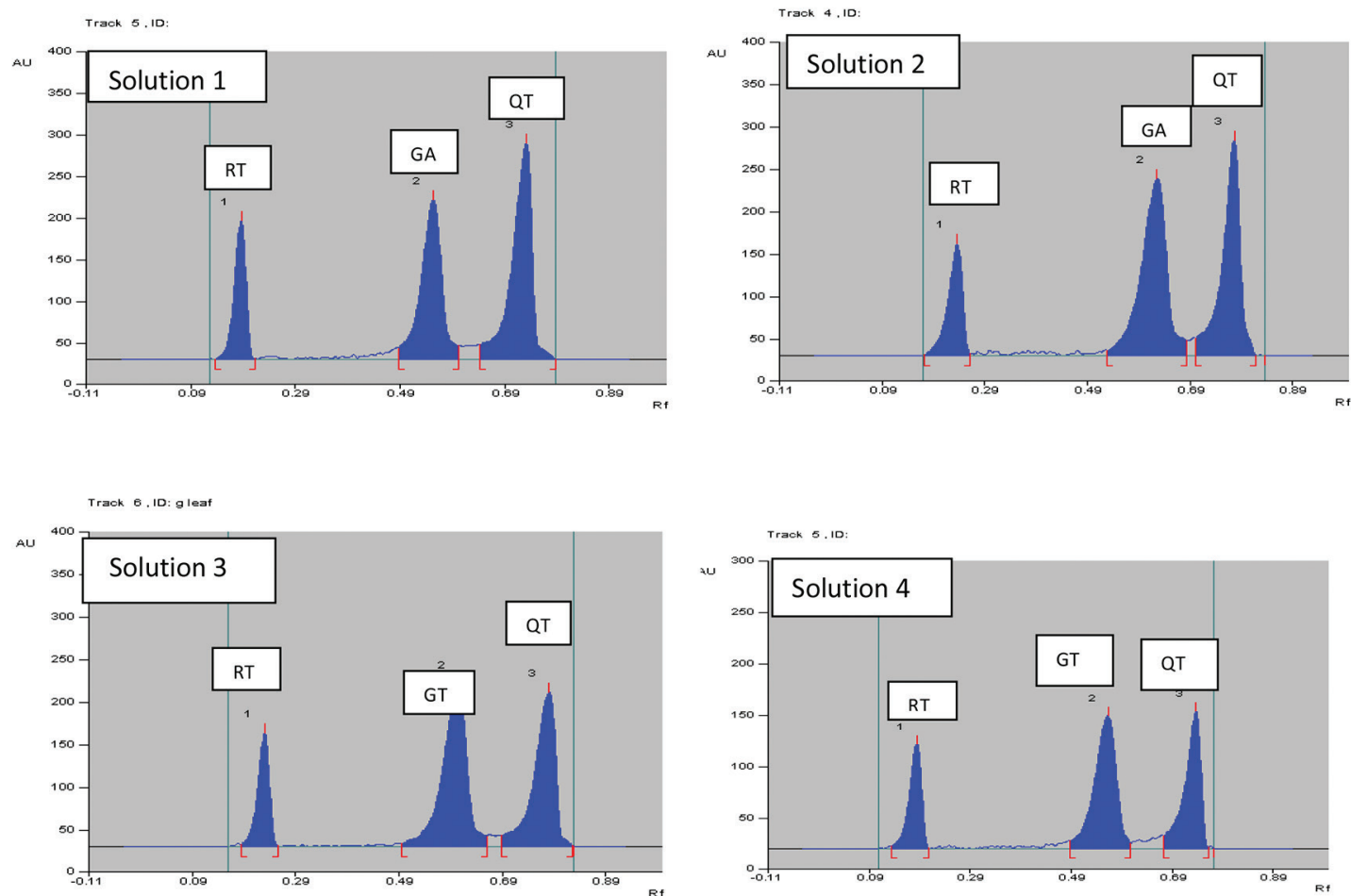

Figure 7. Densitograms of predicted solutions as per design expert software QT: Quercetin, GA: Gallic acid, RT: Rutin

\section{Table 5. Validation data for gallic acid, quercetin, and rutin}

\begin{tabular}{|c|c|c|c|}
\hline Validation parameter & QT & RT & GA \\
\hline \multicolumn{4}{|l|}{ Linearity } \\
\hline Range (ng/band) & $200-1200$ & $200-1200$ & $200-1200$ \\
\hline Regression equation & $y=6.6659 x+1199.1$ & $y=5.0043 x+1443.7$ & $y=13.46 x+1362.1$ \\
\hline$r^{2}$ & 0.9982 & 0.9958 & 0.9951 \\
\hline *Interday precision (Mean \% RSD) & 0.143 & 0.264 & 0.097 \\
\hline *Intraday precision (Mean \% RSD) & 0.370 & 0.182 & 0.161 \\
\hline \multicolumn{4}{|l|}{ Recovery } \\
\hline **Mean \% recovery & 98.75 & 98.66 & 99.16 \\
\hline Mean \% RSD & 1.01 & 0.595 & 0.70 \\
\hline
\end{tabular}

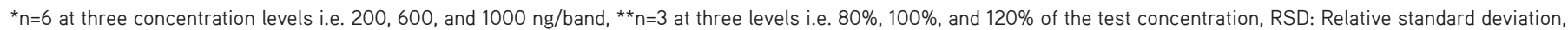
QT: Quercetin, RT: Rutin, GA: Gallic acid

resolved peaks at RF $0.80,0.64$, and 0.22 for $Q T, G A$, and RT, respectively (Figure 8 ). The PDA spectral scan of the separated bands at $300 \mathrm{~nm}$ and the UV spectra generated exactly superimposed with the standard spectra indicating that there was no interference from other components present in the extracts. The photo documentation of the HPTLC plates also displayed distinct bands for the biomarkers when scanned in UV chamber at short wavelength (254 nm) (Figure 8c). It was observed that both the ethanolic and aqueous extracts showed higher content of QT $(993.5 \mu \mathrm{g} / \mathrm{g}$ and $832 \mu \mathrm{g} / \mathrm{g}$, respectively). However, the ethanolic extract showed a larger amount of RT $(701 \mu \mathrm{g} / \mathrm{g})$ when compared to the aqueous extract $(232.2 \mu \mathrm{g} / \mathrm{g})$.

$\begin{aligned} & \text { Table 6. Estimated content of GA, QT, and RT in aqueous and } \\
& \text { ethanolic extracts of Moringa oleifera }\end{aligned}$
\begin{tabular}{lll} 
Biomarker & Aqueous extract & Ethanolic extract \\
\hline GA & $591.1 \mu \mathrm{g} / \mathrm{g}$ & $150 \mu \mathrm{g} / \mathrm{g}$ \\
\hline QT & $832 \mu \mathrm{g} / \mathrm{g}$ & $993.5 \mu \mathrm{g} / \mathrm{g}$ \\
\hline RT & $232.2 \mu \mathrm{g} / \mathrm{g}$ & $701 \mu \mathrm{g} / \mathrm{g}$ \\
\hline
\end{tabular}

QT: Quercetin, RT: Rutin, GA: Gallic acid

In contrast, the aqueous extract exhibited a higher proportion of $\mathrm{GA}(591.1 \mu \mathrm{g} / \mathrm{g})$ as compared to the ethanolic extract (150 $\mu \mathrm{g} / \mathrm{g}$ ) (Table 6). The proposed HPTLC method was successfully 


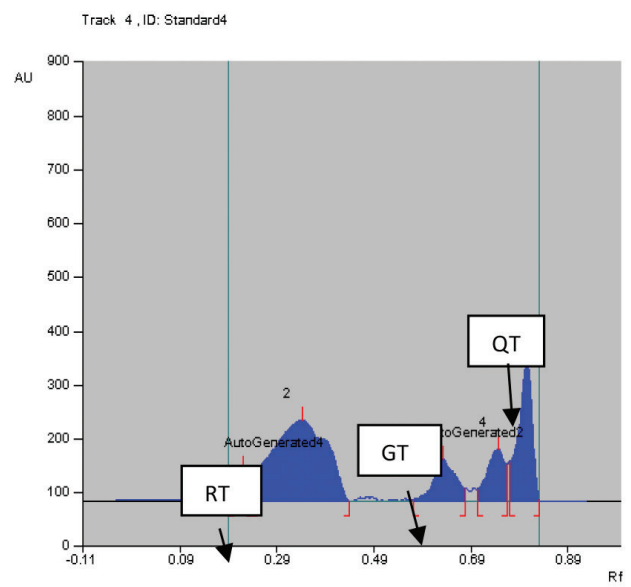

(a)

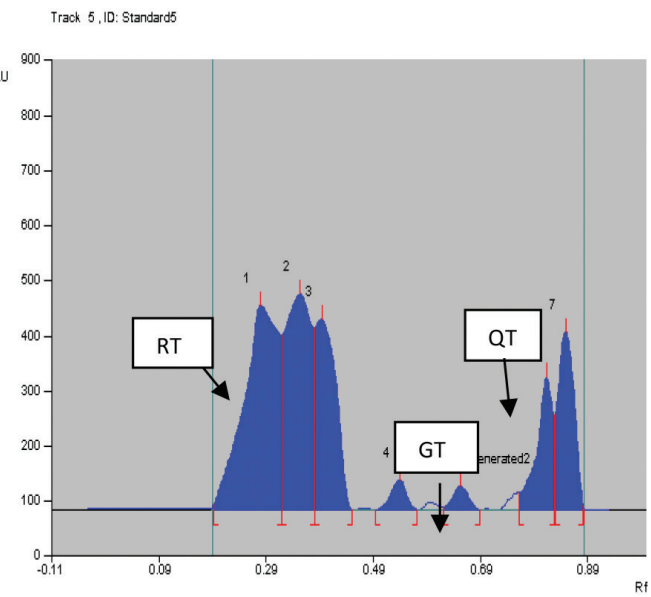

(b)

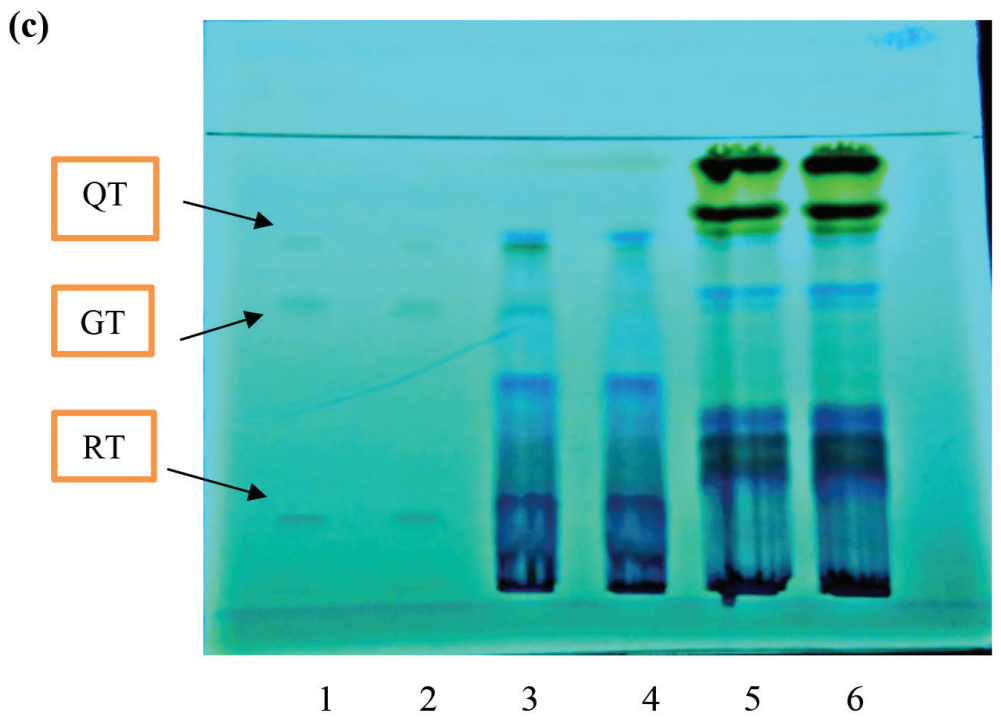

Figure 8. HPTLC densitograms of extracts of Moringa oleifera

(a) For aqueous extract [peak 1, 3 and 5; RT (0.24), GA (0.62) and QT (0.76)]

(b) For ethanolic extract [peak 1, 5 and 6; RT (0.23), GA (0.62) and QT (0.76)]

(c) Photo documentation of developed HPTLC plate Spots of standards (track 1 and 2), aqueous extract (track 3 and 4) and ethanolic extract (track5 and 6) QT: Quercetin, GA: Gallic acid, RT: Rutin, HPTLC: High performance thin layer chromatography

employed for the estimation of these biomarkers in extracts of Moringa oleifera.

Although the literature reports an HPLC method employing a gradient of methanol and acetonitrile for the estimation of these biomarkers in Moringa oleifera plants native to Saudi Arabia by Alam et al. ${ }^{8}$, the RT of these biomarkers are very close to each other $(0.98,0.99$, and 1.04 min for RT, GA, and QU, respectively) and their simultaneous estimation is not possible.

A recent study reports an HPTLC method for estimation of these three biomarkers in Syrian Capparis spinosa L. leaves carried out on precoated silica gel GF254 plates employing a four solvent composition of mobile phase [ethyl acetate- glacial acetic acid-formic acid-distilled water (100:11:11:25)]. Moreover, densitometric scanning was performed at three different wavelengths [366 nm for RT (RF: 0.39), $280 \mathrm{~nm}$ for QT (RF: 0.79), and $254 \mathrm{~nm}$ for GA (RF: 0.81)].15

Some of the more recently reported methods employ separate mobile phase systems for estimation of these three biomarkers [for gallic acid, toulene: formic acid: ethyl acetate: methanol (3:3:8:2, v/v/v/v); for RT and QT, ethyl acetate: formic acid: glacial acetic acid: water (10:0.5:0.5:1.3, v/v/v/v)]. It was also observed that the RF values of QT were very high, which may lead to inadequate quantification as it may overlap with the solvent band. ${ }^{16}$ 
In comparison, the HPTLC method developed by us employs a fixed composition of mobile with quantitative measurement of the three biomarkers at $300 \mathrm{~nm}$ with effective separation leading to distinct bands for the three biomarkers with sufficient differences in their RF values. Moreover, the mobile phase optimized through a DoE approach and method validated as per standard guidelines make it a robust method for their simultaneous quantification.

\section{CONCLUSION}

A sensitive, accurate, and robust HPTLC method was developed for estimation of $\mathrm{QT}, \mathrm{RT}$, and $\mathrm{GA}$ in ethanolic and aqueous extracts of Moringa oleifera using a fixed composition of mobile phase [(toluene: ethyl acetate: menthol: formic acid solution (4.9:4.1:2:0.5 v/v/v/v)] with densitometric analysis at $300 \mathrm{~nm}$. The chromatographic conditions were optimized using a DoE approach and involved use of a regular two level factorial screening design for initial screening of method parameters followed by a CCD for optimization of selected CMPs using Design Expert software. The present study reports for the first time a constant composition of mobile phase for effective separation of QT, RT, and GA and was employed successfully for estimation of these biomarkers in Moringa oleifera extracts. This method may also be extended to estimation of these biomarkers in other herbal extracts, thereby reducing time, and may serve as a cost effective tool for analysis.

\section{ACKNOWLEDGEMENTS}

The authors would like to thank the principal and management of the institute for providing the necessary infrastructural and instrumental facilities to carry out this work.

Conflict of Interest: No conflict of interest was declared by the authors.

\section{REFERENCES}

1. Soleas GJ, Grass L, Josephy PD, Goldberg DM, Diamandis EP. A comparison of the anticarcinogenic properties of four red wine polyphenols. Clin Biochem. 2002;35:119-124.

2. Kroes BH, Van den Berg, AJ, Quarles Van Ufford HC, Van Dijk H, Labadie RP. Anti-inflammatory activity of gallic acid. Planta Med.1992;58:499504.

3. Amir M, Mujeeb M, Ahmad S, Akhtar M, Ashraf K. Design expertsupported development and validation of HPTLC method: an application in simultaneous estimation of quercetin and rutin in Punica granatum, Tamarindus indica and Prunus domestica. Pharm Methods. 2013;4:62-67.
4. Hussain MS, Fareed S, Ali M, Rahman MA. Validation of the method for the simultaneous estimation of bioactive marker gallic acid and quercetin in Abutilon indicum by HPTLC. Asian Pac J Trop Dis. 2012;2:S76-S83.

5. Alam P, Parvez MK, Arbab AH, Al-Dosari MS. Quantitative analysis of rutin, quercetin, naringenin, and gallic acid by validated RP-and NPHPTLC methods for quality control of anti-HBV active extract of Guiera senegalensis. Pharm Biol. 2017;55:1317-1323.

6. Seal T. Quantitative HPLC analysis of phenolic acids, flavonoids and ascorbic acid in four different solvent extracts of two wild edible leaves, Sonchus arvensis and Oenanthe linearis of North-Eastern region in India. J Appl Pharm Sci. 2016;6:157-166.

7. Huang $Y$, Sun $H Y$, Qin $X L$, Li YJ, Liao SG, Gong ZP, Lu Y, Wang YL, Wang AM, Lan YY, Zheng L. A UPLC-MS/MS method for simultaneous determination of free and total forms of a phenolic acid and two flavonoids in rat plasma and its application to comparative pharmacokinetic studies of Polygonum capitatum extract in rats. Molecules. 2017;22:353-368.

8. Alam P, Elkholy SF, Mahfouz SA, Prawez A, Mahmoud A, Eldin, S. HPLC based estimation and extraction of rutin, quercetin and gallic acid in Moringa oleifera plants grown in Saudi Arabia. J Chem Pharm. 2016;8:1243-1246.

9. Phansawana B, Pongsabangpho S. Determination of gallic acid and rutin in extracts Cassia alata and Andrographis paniculata. Science Asia. 2014:40:414-419.

10. Sajeeth $\mathrm{Cl}$, Manna PK, Manavalan R, Jolly Cl. Quantitative estimation of gallic acid, rutin and quercetin in certain herbal plants by HPTLC method. Der Chemica Sinica. 2010;1:80-85.

11. Kumar A, Lakshman K, Jayaveera KN, Satish KV. Estimation of gallic acid, rutin and quercetin in Terminalia chebula by HPTLC. JJPS. 2010;3:63-67.

12. Kesharwani S, Prasad P, Roy A, Sahu RK. An overview on phytochemistry and pharmacological explorations of Moringa oleifera. UKJPB. 2014:2:34-41.

13. Shah P, Patel J, Patel K, Gandhi T. Development and validation of HPTLC method for simultaneous estimation of Clonazepam and Paroxetine hydrochloride using DOE approach. JTUSCI. 2017;11:121-132.

14. Vongsak B, Sithisarn P, Mangmool S, Thongpraditchote S, Wongkrajang Y, Gritsanapan W. Maximizing total phenolics, total flavonoids contents and antioxidant activity of Moringa oleifera leaf extract by the appropriate extraction method. Ind Crops Prod. 2013;44:566-571.

15. Hussain J, Bassal M, Sarhan H, Aga MIH. Qualitative and quantitative comparison of rutin, quercetin and gallic acid concentrations in Syrian Capparis spinosa. L leaves. J Pharmacogn Phytochem. 2017;6:407-415.

16. Marathe VR, Umate SK, Estimation of gallic acid, rutin and quercetin in Portulaca quadrifida L. - a potential wild edible plant by HPTLC method. Int J Life Sciences. 2016;4:83-88. 